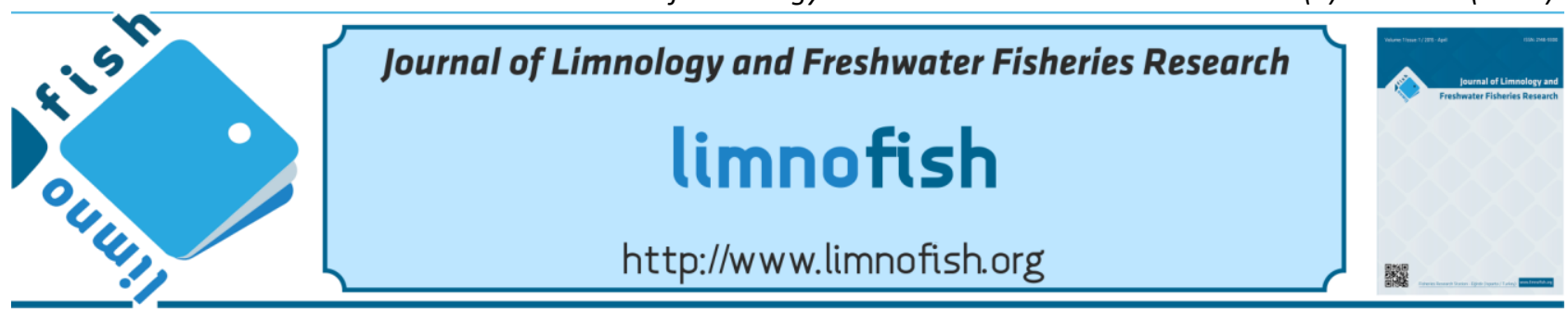

\title{
Actual Status of Eber Lake in Terms of Fish Community Structure
}

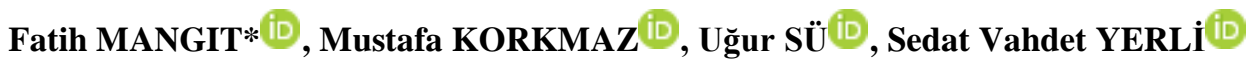 \\ Hacettepe University, Science Faculty, Department of Biology, SAL, Ankara, Turkey
}

\section{A B STRACT}

Lake Eber is a small, shallow tectonic lake, located in the central part of Anatolia. Lake is under effect of pollution and exotic fish species. In order to define environmental degradation within the lake and its effects on fish assembly in a historical perspective field study was conducted. Water sampling was conducted seasonally between December, 2012 and September, 2013. Physico-chemical paramaters as dissolved oxygen, $\mathrm{pH}$, total phosphorus and total Kjeldahl nitrogen was assessed. Trophic state index was calculated from phosphorus concentrations and trophic state of the lake was assessed. Fishing was carried out in April, 2013, on randomly selected eight stations with benthic multimesh nets ( $30 \mathrm{~m}$ long, 1.5 $\mathrm{m}$ depth, 12 different mesh size from $5 \times 5 \mathrm{~mm}$ to $55 \times 55 \mathrm{~mm}$ ) and fyke net. Fish assembly, catch data (catch per unit effort), length-weight relationships of the species with enough sample size is reported.

Keywords: Fish fauna, length-weight relationship, eutrophication, Afyonkarahisar

\section{ARTICLE INFO}

\section{RESEARCH ARTICLE}

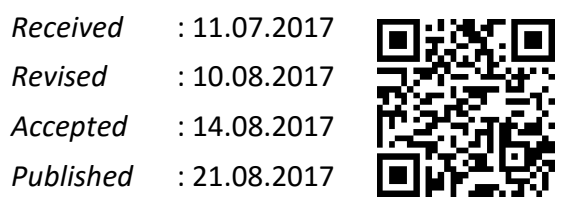

DOI: 10.17216/LimnoFish.327824

\section{* CORRESPONDING AUTHOR}

fatihmangit@gmail.com

Tel : +903122976785

\section{Eber Gölü’nün Balık Komunite Yapısı Açısından Güncel Durumu}

Öz: Eber Gölü, İç Anadolu Bölgesi’nde bulunan küçük ve sığ bir tektonik göldür. Göl kirlenme ve egzotik balık türlerinin baskısı altındadır. Tarihsel çerçevede, göldeki çevresel bozunmayı tanımlamak ve bunun balık toplulukları üzerindeki baskısını tanımlamak amacıyla alan çalışmaları gerçekleştirilmiştir. Su örneklemesi Aralık, 2012 ile Eylül, 2013 tarihleri arasında gerçekleştirilmiştir. Çözünmüş oksijen, pH, toplam fosfor ve toplam Kjeldahl azotu gibi fiziko-kimyasal özellikler belirlenmiştir. Fosfor konsantrasyonları üzerinden trofik statü indeksi hesaplanmış ve trofik statü değerlendirilmiştir. Balık avcılığı, sekiz farklı istasyonda, bentik çok gözlü ağlar (30 m uzunluğunda, 1,5 m eninde, $5 \times 5$ ila $55 \times 55 \mathrm{~mm}$ göz açıklı̆̆nda) ve pinter ile Nisan, 2013 tarihinde gerçekleştirilmiştir. Balık toplulukları, av verisi (birim av çaba), yeterli sayıda örnek bulunan türlerin boy-ağırlık ilişkileri rapor edilmiştir.

Anahtar kelimeler: Balık faunası, boy-ağırlık ilişkisi, ötrifikasyon, Afyonkarahisar

How to Cite

Mangit F, Korkmaz M, Sü U, Yerli SV. 2017. Actual Status of Eber Lake in Terms of Fish Community Structure. 3(2):101-106. doi: 10.17216/LimnoFish.327824

\section{Introduction}

Lake Eber is a small, shallow tectonic lake, located in the central part of Anatolia, it is surrounded by Emir Mountains from the south and Sultan Mountains from the north (Atalay 1977; Köle et al. 2016). Eber is the biggest lake in the Akarçay River Basin after drying of Akşehir Lake. Basin which the lake resides is a closed basin, made up mainly by Akarçay River which is also the main influent into the lake. Changes in climatic conditions which are effecting the water regime, and anthropological activities are the main threats for the basin and lake itself.
Eutrophication is the process of nutrient accumulation causing water body to become more productive (Moss 1988). This process promotes algal blooms causing high variations in dissolved oxygen content of water and can cause release of bloom related algal toxins. From fisheries perspective, all this can lead to fish deaths and in the long term changes in fish fauna. In addition to this environmental degradation, presence of exotic species can speed up this process. Introduction of fish species can alter ecosytem and effect biodiversity by means of predation, competition, hybridization and habitat alteration (Cowx 1998). 
Lake Eber is under effect of these anthropogenic pressures. This study aims to define environmental degradation within the lake and its effects on fish assembly in a historical perspective.

\section{Materials and Methods}

Water sampling was conducted seasonally between December, 2012 and September, 2013 whereas fish sampling was conducted in April, 2013. Physico-chemical parameters such as dissolved oxygen (DO; $\mathrm{mg} / \mathrm{l})$ and $\mathrm{pH}$ were recorded in situ with YSI 5739 and YSI 33 SCT meter respectively. Chemical parameters such as total phosphorus (TP; $\mathrm{mg} / \mathrm{l}$ ), total Kjeldahl nitrogen (TKN; mg/l) was analyzed in an accredited laboratory conditions (OSİB SYGM 2013).

In order to determine trophic status of the lake Trophic State Index (TSI) developed by Carlson (1977) is used. Trophic state according to total phosphorus $\left(T S I_{T P}\right)$ is calculated using the formula below.

$$
T S I_{T P}=10\left(6-\left(\frac{\ln \left(\frac{48}{T P}\right)}{\ln (2)}\right)\right.
$$

Fishing was carried out on 8 stations with benthic multimesh nets ( $30 \mathrm{~m}$ long, $1.5 \mathrm{~m}$ depth, 12 different mesh size from $5 \times 5 \mathrm{~mm}$ to $55 \times 55 \mathrm{~mm}$ ) and fyke net following TS EN 14757 sampling standart. Due to low water depth, no significant stratification was observed in the lake and benthic positioning of the multimesh gillnets sufficiently sampled the water column. Species identification were done according to Battalgil 1944, Bogutskaya 1997, Geldiay \& Balık 2007; Kuru et al. 2014. Total length $(T L)$, Fork length $(F L)$ and Standart length $(S L)$ were measured to nearest millimeter with ruler (TL>15 $\mathrm{cm})$ and digital caliper (TL<15 cm). Weighing was conducted with analog and digital scales. Sampled fish were kept in ice until all measurements were finished.

Catch per unit effort (CPUE) was reported as number of specimens and grams of fish catch per multimesh net. Length weight relationships were calculated using the Ricker (1975) (LWR) model $\left(W=a T L^{b}\right)$; in which $W$ is total weight $(\mathrm{g})$, $T L$ is total length $(\mathrm{cm}), \mathrm{a}$ and $\mathrm{b}$ are the equation parameters calculated by the least squares method using the logarithmic form of the equation. Significance of the regression was reported by the correlation coefficient of the regression $\left(\mathrm{R}^{2}\right)$, and signifficant differences from isometric growth $\left(H_{0}: b\right.$ $=3$ ) were assessed $(p)$. LWR and frequence analyses were conducted with FSA package (Ogle 2014) developed for R 3.4.0 (R Core Team 2014).

\section{Results}

\section{Properties of water body}

Physico-chemical properties of the water is summarised in Table 1 with the results of similar analysis reported in Günay et al. (1985) and Kazanc1 et al. (1999) for comparison. Phosphorus concentration from Akşehir Lake is added from Numann (1958) since at this date lakes connect at certain dates throughout the year. Phosphorus levels for Eber Lake can be lower than this value $(0.02 \mathrm{mg} / \mathrm{L})$ since Akşehir Lake is the last residence for water in the basin.

Water $\mathrm{pH}$ seems to show variances throughout the year and there seems to be a shift to the basic side when compared to previous readings. High values of total phosphorus and nitrogen compounds seem to indicate eutrophic conditions. Nitrogen compounds seem to increase significantly over the years. Trophic state index scores for total phosphorus $\left(T S I_{T P}\right)$ was high and indicating hypereutrophic tendency after 1980's. Rather than showing a recovery or stabilization, these values showed a significant increase after these dates.

Table 1. Some physico-chemical parameters for Lake Eber with TSI values calculated for TP

\begin{tabular}{ccccccc}
\hline & DO * & $\mathrm{pH}$ & $\mathrm{TP} *$ & $\mathrm{TKN} *$ & Reference & $\begin{array}{c}\text { TSI } \\
(\mathrm{TP})\end{array}$ \\
\hline 1954 & - & - & $0.02 * *$ & - & $\begin{array}{c}\text { Numann } \\
(1958)\end{array}$ & 47.37 \\
\hline 12.1982 & - & - & 0.13 & 1.80 & & 74.37 \\
03.1983 & - & - & 0.07 & 2.23 & & 65.44 \\
04.1983 & - & - & 0.02 & 0.98 & Günay et al & 47.37 \\
06.1983 & - & - & 0.15 & 2.18 & $(1985)$ & 76.44 \\
08.1983 & - & - & 0.10 & 3.58 & & 70.59 \\
10.1983 & - & - & 0.10 & 1.48 & & 70.59 \\
\hline 06.1996 & 6.70 & 7.06 & - & - & Kazanc1 et al & - \\
05.1998 & 5.60 & 7.10 & - & - & $(1999)$ & - \\
\hline 11.2012 & 9.62 & 8.63 & 0.46 & 5.48 & & 92.61 \\
03.2013 & 14.11 & 9.25 & 0.34 & 2.01 & & 88.10 \\
06.2013 & 14.00 & 8.94 & 0.34 & 4.67 & & 88.10 \\
09.2013 & 9.63 & 9.40 & 0.34 & 12.18 & & 88.39 \\
\hline
\end{tabular}

* mg/l, ** Values from Akşehir Lake

\section{Fish assembly and LWR}

A total of 3280 specimens of seven fish species were sampled from the lake. These species are Alburnus nasreddini Battalgil, 1943; Cyprinus carpio Linnaeus, 1758; Carassius gibelio (Bloch, 1782); Tinca tinca (Linnaeus, 1758); Seminemacheilus lendlii (Hanko, 1925); Cobitis simplicispina Hanko, 1925 and Knipowitschia caucasica (Berg, 1916). Sampled fish specimens, their total weight, catch per unit effort (CPUE) and 
Length-weight relationships (LWRs) of the species with enough sample size is given in Table 2.

Model fit is successive for A. nasreddini, C. gibelio and $C$. simplicispina. However, coefficient for determination $\left(\mathrm{R}^{2}\right)$ value for $S$. lendlii is 0.71 indicating $a$ failure in model fit possibly due to variative weights at same length rather than sample size. All $b$ values for the species (except $S$. lendlii) with enough number of specimens for the model are over three indicating $a$ positive allometry. Lengthweight relationship plots, residuals of the regression model and frequency analysis of A. nasreddini, C. gibelio, $C$. simplicispina and $S$. lendlii are illustrated between Figures 1-4.
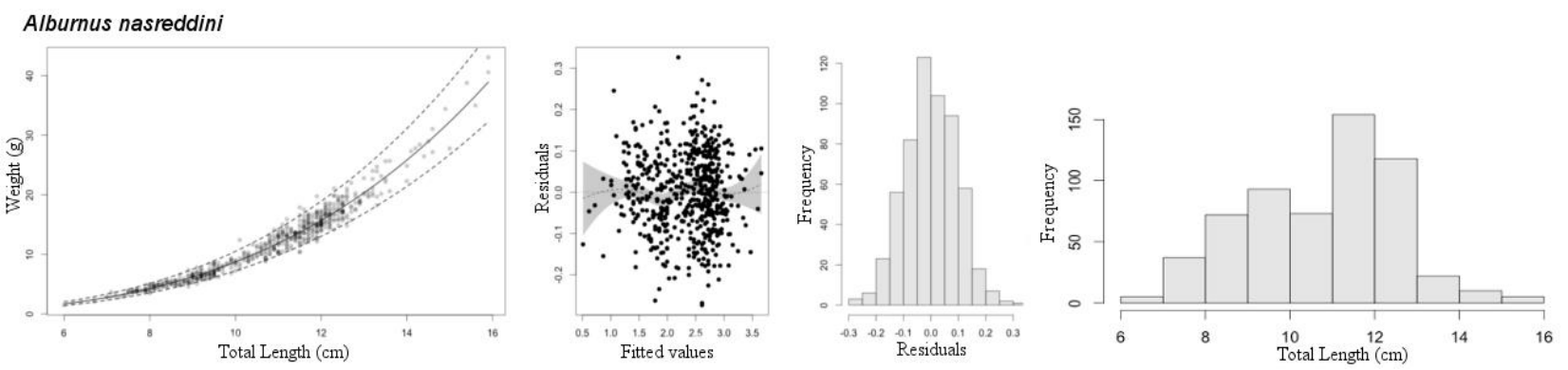

Figure 1. A. nasreddini length weight relationship plot, regression model fit plots and length frequency
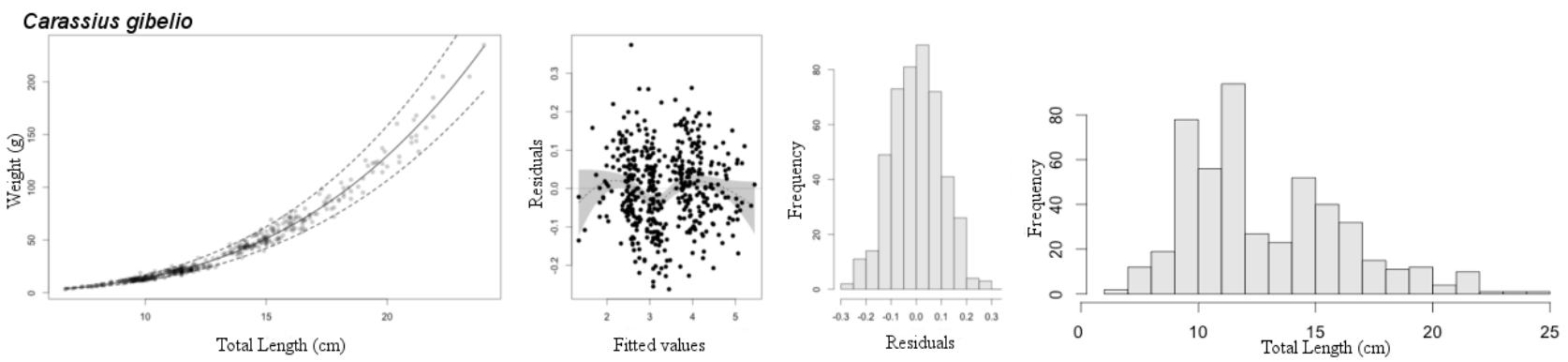

Figure 2. C. gibelio length weight relationship plot, regression model fit plots and length frequency
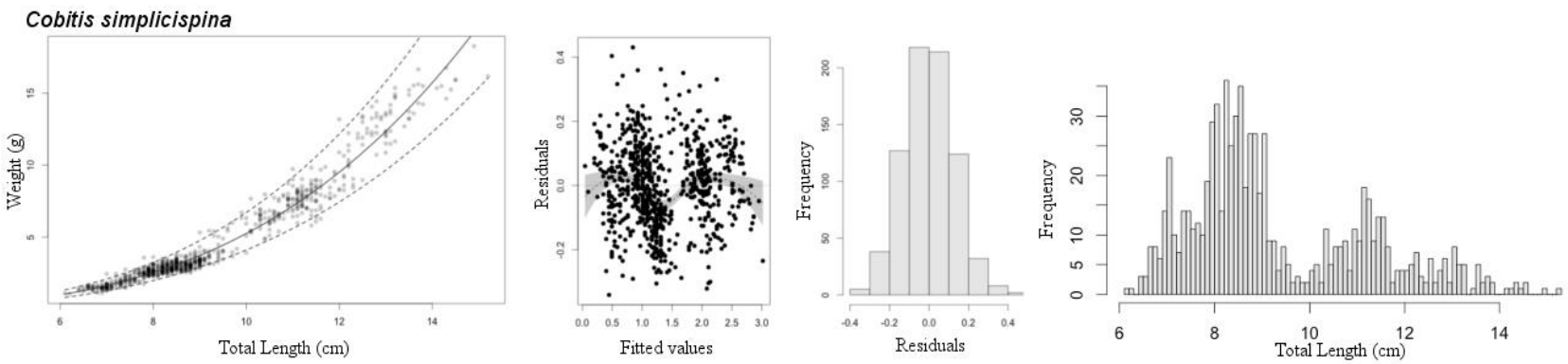

Figure 3. $C$. simplicispina length weight relationship plot, regression model fit plots and length frequency
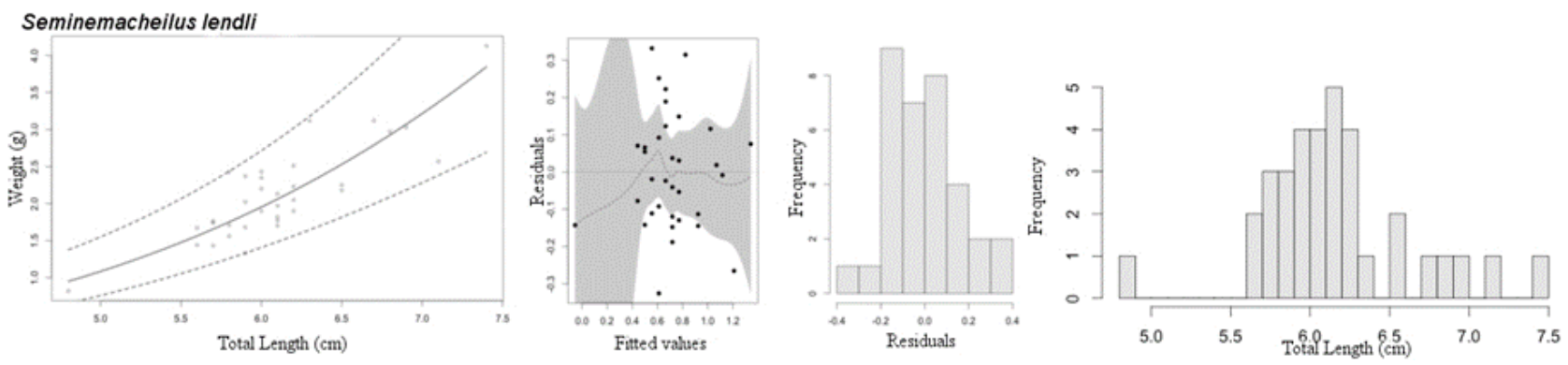

Figure 4. S. lendlii length weight relationship plot, regression model fit plots and length frequency 
Table 2. Fish abundance and length weight relationship values

\begin{tabular}{|c|c|c|c|c|c|c|c|c|c|c|c|c|c|}
\hline \multirow[b]{2}{*}{ Species } & \multirow[b]{2}{*}{ Total $\mathrm{n}$} & \multirow[b]{2}{*}{ Weight (g) } & \multicolumn{2}{|c|}{ CPUE $^{*}$} & \multirow[b]{2}{*}{ LWR n } & \multicolumn{2}{|c|}{$\mathrm{TL}(\mathrm{cm})$} & \multicolumn{2}{|c|}{$\mathrm{W}(\mathrm{g})$} & \multicolumn{4}{|c|}{ Regression Parameters } \\
\hline & & & (n) & (g) & & Min. & Max. & Min & $\operatorname{Max}$ & $a$ & $b \pm \mathrm{SE}$ & $\mathrm{R}^{2}$ & $\mathrm{p}$ \\
\hline A. nasreddini & 1115 & 7709.97 & 139.38 & 12437.25 & 577 & 6 & 15.9 & 1.47 & 43.05 & 0.0051 & $3.23 \pm 0.02$ & 0.97 & 0.001 \\
\hline C. gibelio & 1149 & 32774.8 & 143.63 & 36716.29 & 466 & 6.7 & 24.0 & 3.33 & 235.00 & 0.0083 & $3.22 \pm 0.02$ & 0.99 & 0.001 \\
\hline S. lendlii & 74 & 138.35 & 9.25 & 149.82 & 34 & 4.8 & 7.4 & 0.82 & 4.13 & 0.0059 & $3.23 \pm 0.35$ & 0.71 & 0.514 \\
\hline C. simplicispina & 925 & 4250.11 & 115.63 & 4306.15 & 768 & 6.1 & 15.2 & 1.08 & 18.26 & 0.0029 & $3.26 \pm 0.02$ & 0.96 & 0.001 \\
\hline T. tinca & 4 & 29.2 & 0.38 & 29.2 & - & - & - & - & - & - & - & - & - \\
\hline K. caucasica & 3 & 1.93 & 0.38 & 1.93 & - & - & - & - & - & - & - & - & - \\
\hline C. carpio & 10 & & & & & & & & & & & & \\
\hline
\end{tabular}

${ }^{*}$ Catch per unit effort: Catch per multimesh net $(30 \mathrm{~m})$

\section{Discussion}

Elements which can be helpful to determine water quality is showing that lake is hypertrophic. Most of the parameters reach levels that can be classified as the worst class (class IV) according to criteria for water quality (SKKY 2004). Increased pH is typical for eutrophic lakes as can be seen in Lake Mogan (Mangit and Yerli 2010) and Lake Uluabat (Elmac1 et al. 2009), similar shallow lakes with hypertrophy tendency. Oxygen levels in lake seem to be high throughout the year. This over saturation with oxygen is typical in shallow lakes with dense submerged macrophytes as Lake Eber. Phosphorus (TP) and nitrogen compounds (TKN) seem to increase over the years compared to Günay et al. (1985) and Kazanc1 et al. (1999).

Fish sampling data revealed that A. nasreddini and $C$. gibelio is widespread in the lake whereas S. lendlii, C. simplicispina, C. carpio, T. tinca and $K$. caucasica are not caught by every gillnet. C. gibelio seem to dominate fish populations in the lake by means of indiviuals and biomass. According to results this invasive fish species constitutes $35 \%$ of the fish specimens and $73 \%$ of fish biomass. By means of population size it is followed closely by $A$. nasreddini (34\%) and C. simplicispina (28\%) however in terms of biomass it is by far the dominant species. Invasion potential of $C$. gibelio is demonstrated clearly in Lake Eber. A. nasreddini constitues $34 \%$ of the specimens sampled. Eber Lake is the type locality of A. nasreddini and this species is listed under Critically Endangered status by IUCN (2017) due to pollution and desiccation. However high the CPUE may seem in this study it is clearly under threat of $C$. gibelio.

This recent fauna is a consequence of pollution brought by Akarçay River and fisheries activities. In this study E. lucius and C. carpio can not be sampled by gillnets however the latter is sampled by fyke nets. Both species are present in the lake however according to fisherman catch of these species dropped significantly as it can be interpreted from gillnet catch results. In addition to this decrease in economically important species C. carpio and E. lucius, T. tinca is under serious fishing pressure too. Only four specimens were caught in this study.

Fish fauna is compared to the previous studies in order to interpret long term changes in the lake (Table 3). Changes in fish fauna and environmental degradation through the years summarised in Figure 5.

C. carpio and E. lucius assumed to have a natural distribution in Turkey however both of them are translocated extensively (İnnal and Erk'akan 2006, İnnal 2012, Tarkan et al. 2015). But due to having a report in the beginning of 1900's, these species are listed under native status. A. nasreddini has not been reported by Deveciyan (1915), but due to similar lateral line scale count it can be mistaken as Rutilus rutilus (Linnaeus, 1758). In addition to this possible confliction, Deveciyan (1915) reported 3 more species namely, C. carpio, E. lucius and Squalius recurvirostris Özuluğ \& Freyhof, 2011 (given as Leuciscus cephalus). Other species were probably distributed in the lake however main focus at these years were fisheries rather than biological diversity. Therefore we colored these boxes as gray to indicate this probability. Following Deveciyan (1915), no reports had been found until Kosswig (1952). In this study by Kosswig, fauna for Eber Lake with Akşehir Lake combined since at that time connection between these lakes was not distrupted. And to our knowledge this was the first and last detailed report about the lake. There seems to be drastic changes in the fish fauna over the years. C. gibelio seem to enter this lake after 2000's and possibly with the help of environmental degradation it became the dominant species. Species with possible low tolerance to eutrophication such as 
Gobio intermedius Battalgil, 1944 and $S$. recurvirostris are replaced by tolerant C. gibelio, K. caucasica and T. tinca.

In order to restore the lake, pollution need to be controlled. However even if influent is controlled there won't be an immediate shift to eutrophic state. Water quality of the lake need to be monitored closely and possibly some other measures can be taken to control eutrophication. Also fisheries activities need to be monitored carefully and measures to remove $C$. gibelio from the lake need to be considered.

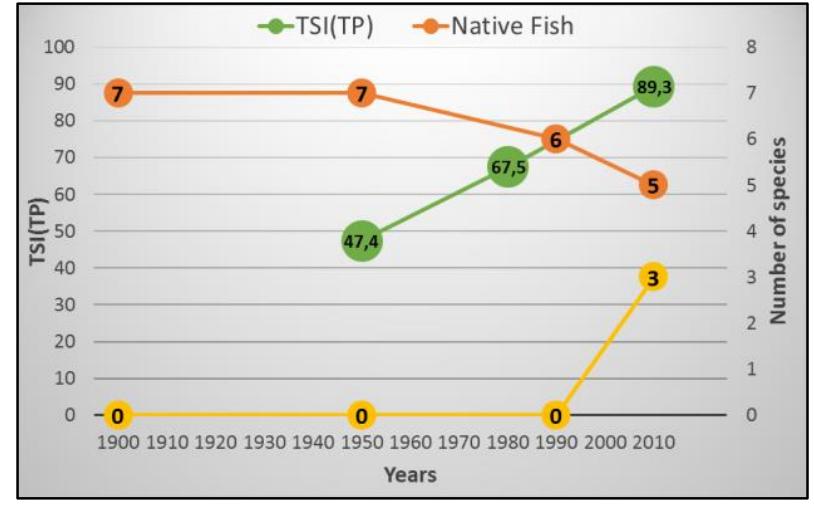

Figure 5. Environmental degradation and fish fauna in Lake Eber

Table 3. Fish fauna comparison for Lake Eber

\begin{tabular}{|c|c|c|c|c|c|}
\hline & & $\begin{array}{c}\text { Deveciyan } \\
1915\end{array}$ & $\begin{array}{c}\text { Kosswig } \\
1952\end{array}$ & $\begin{array}{c}\text { Kazanc1 et al. } \\
1999\end{array}$ & This study \\
\hline \multicolumn{6}{|l|}{ Native Species } \\
\hline Alburnus nasreddini ${ }^{(1)}$ & Battalgil, 1943 & & & & \\
\hline Cobitis simplicispina ${ }^{(2)}$ & Hankó, 1925 & & & & \\
\hline Gobio intermedius ${ }^{(3)}$ & Battalgil, 1944 & & & & \\
\hline Rutilus rutilus ${ }^{(4)}$ & (Linnaeus, 1758) & & & & \\
\hline Seminemacheilus lendlii & (Hankó, 1925) & & & & \\
\hline Squalius recurvirostris ${ }^{(5)}$ & Özulug \& Freyhof, 2011 & & & & \\
\hline Cyprinus carpio & Linnaeus, 1758 & & & & \\
\hline Esox lucius & Linnaeus, 1758 & & & & \\
\hline \multicolumn{6}{|l|}{ Exotic Species } \\
\hline Carassius gibelio & (Bloch, 1782) & & & & \\
\hline Ctenopharyngodon idella ${ }^{(6)}$ & (Valenciennes, 1844) & & & & \\
\hline Knipowitschia caucasica & (Berg, 1916) & & & & \\
\hline Tinca tinca & (Linnaeus, 1758) & & & & \\
\hline
\end{tabular}

1) It has been reported as Alburnus orontis, Alburnus alburnus and Alburnus nasreddini. 2) It has been reported as Cobitis taenia. 3) It has been reported as Gobio gobio and Gobio gobio intermedius. 4) It has been reported as Leuciscus rutilus. 5) It has been reported as Leuciscus cephalus and Leuciscus lepidus. 6) It was released for macrophyte control, sampled in 2008 (DKMPGM 2008), but no reports since.

\section{Acknowledgements}

This study was conducted with ALKA, HT-TTM, HU SAL in a project supported by Republic of Turkey, Ministry of Forestry and Water Affairs General Directorate of Water Management. Part of this study was presented in Ecology Symposium, 7-9 May 2015, Sinop-Turkey as poster presentation.

\section{References}

Atalay İ. 1977. Sultandağları ile Akşehir ve Eber gölü havzalarının strüktüral, jeomorfolojik ve toprak erozyonu etüdü, Erzurum: Atatürk Üniversitesi. 260 p. [in Turkish]

Battalgil F. 1944. Nouveaux poisons des eaux douces de la Turquie. Revue de la Faculté des Sciences de l'Université d'Istanbul, Série B, Sciences Naturelles, 9(2): 126-133.
Bogutskaya NG. 1997. Contribution to the knowledge of leuciscine fishes of Asia Minor. Part. 2. An annotated check-list of leuciscine fishes (Leuciscinae, Cyprinidae) of Turkey with descriptions of a new species and two new subspecies. Mitt. Hamb. Zool. Mus. Inst., 94: 161-186.

Carlson RE. 1977. A trophic state index for lakes. Limnol Oceanogr. 22(2): 361-369. doi:10.4319/lo.1977.22.2.0361

Cowx IG. 1998. Stocking and introduction of fish. Fishing News Books 504 p.

Deveciyan K. 1915. Türkiye'de balık ve balıkçılık 'Pêche et pêcheries en Turquie'. İstanbul: Aras Yayıncılık 574 p. [in Turkish]

DKMPGM (T.C. Çevre ve Orman Bakanlığı, Doğa Koruma ve Milli Parklar Genel Müdürlüğü). 2008. Akşehir Eber gölleri sulak alan yönetim planı (20082012), 223 p. [in Turkish] 
Elmacı A, Ozengin N, Teksoy A, Topac FO, Baskaya H. 2009. Evaluation of trophic state of lake Uluabat, Turkey. J Env Biol. 30(5): 757-760.

Geldiay R, Balık S. 2007. Türkiye tatlısu balıkları. İzmir: Ege Üniversitesi Basımevi 638 p. [in Turkish]

Günay Y, Durusu A, Tabuman FC. 1985. Isparta ve yöresindeki göllerde su kalitesi evsel ve endüstriyel atıklarla ilgili parametreler. Ankara: TÜBİTAK. Project No: ÇAG-47 [in Turkish]

İnnal D. 2012. Alien fish species in reservoir systems in Turkey: a review. Manag Biol Invasion. 3(2): 115-119. doi:10.3391/mbi.2012.3.2.06

İnnal D. Erk'akan F. 2006. Effects of exotic and translocated fish species in the inland waters of Turkey. Rev Fish Biol Fish. 16(1): 39-50. doi:10.1007/s11160-006-9005-y

IUCN 2017. The IUCN Red List of Threatened Species. Version 2017-1; [Cited 2017 July 03]. Available from http://www.iucnredlist.org.

Kazancı N, Girgin S, Dügel M, Oğuzkurt D, Mutlu B, Dere Ş, Barlas M, Özçelik M. 1999. Köyceğiz, Beyşehir, Eğirdir, Akşehir, Eber, Çorak, Kovada, Yarışlı, Bafa, Salda, Karataş, Çavuşçu gölleri, Küçük ve Büyük Menderes Deltası, Güllük Sazlığı ve Karamuk Bataklığı'nın limnolojisi, çevre kalitesi ve biyolojik çeşitliliği, Türkiye İç Suları Araştırmaları Dizisi IV, Ankara: 371 p. [in Turkish]

Kosswig C. 1952. Zoogeographie fer türkischen Süsswasserfische. Hidrobiologie İstanbul Ser. B. 1(2): 85-101.

Köle MM, Ataol M, Erkal T. 2016. Eber ve Akşehir gölleri'nde 1990-2016 yılları arasında gerçekleşen alansal değişimler. Paper presented at: TÜCAUM Uluslararası Coğrafya Sempozyumu; Ankara, Turkey. [in Turkish]
Kuru M, Yerli SV, Mangıt F, Ünlü E, Alp A. 2014. Fish biodiversity in inland waters of Turkey. Journal of Academic Documents for Fisheries and Aquaculture, 1(3): 93-120.

Mangit F, Yerli SV. 2010. An approach for trophic gradient in Lake Mogan (Turkey): A shallow eutrophic lake. Hacettepe J Biol \& Chem. 38(1): 41-45.

Numann W. 1958. Anadolu'nun muhtelif göllerinde limnolojik ve balıkçılık ilmi bakımından araştırmalar ve bu göllerde yaşayan sazanlar hakkında özel bir Etüt. İstanbul Üniversitesi Fen Fakültesi Hidrobiyoloji Araştırma Enstitüsü Yayınları Monografi 7, 114 p. [in Turkish]

Moss B. 1988. Ecology of fresh waters: Man and Medium, $2^{\text {nd }}$ edition. Oxford: Blackwell Scientific Publications $417 \mathrm{p}$.

Ogle DH. 2014. FSA: Fisheries Stock Analysis. R package version 0.4.31.

$\mathrm{R}$ Core Team. 2014. R: A language and environment for statistical computing, $\mathrm{R}$ foundation for statistical computing, Vienna, Austria, http://www.R-project.org.

Ricker WE. 1975. Computation and interpretation of biological statistics of fish populations. Bull Fish Res Bd Can. 191: 1-382.

SKKY. 2004. Su Kirliliği Kontrolü Yönetmeliği. Resmi Gazete, No: 25687.

OSİB SYGM (Orman ve Su İşleri Bakanlığı Su Yönetimi Genel Müdürlüğü). 2013. Havza izleme ve referans noktalarının belirlenmesi projesi Akarçay Nehri Havzası, ALKA, HT-TTM, HU SAL [In Turkish]

Tarkan AS, Marr SM, Ekmekçi FG. 2015. Non-native and translocated freshwater fish. FISHMED. 3: 28.

TS EN 14757. 2015. Water quality. Fish sampling with multi-mesh gillnets. 